\title{
M. Moravčíková
}

\section{THE QUESTION OF SECULAR STATE, RECOGNITION OF RELIGIOUS SUBJECTS AND THEIR ECONOMICAL SUPPORT ${ }^{1}$}

This paper deals with the relationship between the State and Churches in Slovakia. The most significant measure of secularity of the State is considered the approach to the religion in the public sphere and recognition of Churches and religious societies. New religious movements also seek to gain the status of an official church. Efforts are complicated by the small number of their members. The State usually argued by the principle of a differentiated parity, reference to the historical development and religiousdemographic situation. It raises a further question the safety of children, individuals, families and society in the context of recognizing of new religious subjects. At present, it seems the conditions for registration of churches will be stricter because of general security situation in Europe.

Another important area is the financing support of churches by the State. Direct funding from the state budget is often criticized as a relic of communism. These areas are the biggest challenge for the development of the State law governing State-Church relations. The State has to create such a StateChurch Law system which allows a maximum degree of religious freedom and autonomy of Churches and religious societies. Therefore, it is still a topical issue about the limits of collective expression of freedom of religion and the question of financing of Churches and religious societies from the State Budget. Refs 7.

Keywords: State Church relations, religion, recognition of churches and religious societies, financial support of churches.

\section{М. Моравчикова}

\section{ВОПРОС О СВЕТСКОМ ГОСУДАРСТВЕ, ПРИЗНАНИЕ РЕЛИГИОЗНЫХ СУБЪЕКТОВ И ИХ ЭКОНОМИЧЕСКАЯ ПОДДЕРЖКА}

В статье рассматриваются вопросы взаимоотношений между государством и церквями в Словакии. Наиболее значимыми показателями светскости государства считаются соблюдение принципов свободы совести, взаимодействие между различными религиями и государством в общественной сфере, признание церквей и религиозных обществ. Новые религиозные движения также стремятся получить официальный статус в государстве. Это бывает достаточно сложно по причине небольшого числа членов этих религиозных организаций. Государства, как правило, утверждают принцип дифференцированного паритета, ссылаясь на исторические традиции и религиозно-демографическую ситуацию. Также важными являются проблемы безопасности детей, отдельных лиц, семей и общества в контексте признания новых религиозных субъектов. В настоящее время формируется мнение о необходимости усложнения условий регистрации церквей в целях общей безопасности в Европе. Другим важным направлением является финансирование церквей со стороны государства. Прямое финансирование из государственного бюджета часто подвергается критике как пережиток коммунизма. Эти вопросы являются самыми актуальными в области совершенствования законодательства, регулирующего государственно-церковные отношеня. Государство в европейских странах должно создать такую систему государственно-церковного права, которая будет допускать максимальную степень религиозной свободы и автономии церквей и религиозных обществ. Таким обра-

Моравчикова Михаэла - доктор теологии, директор Института по правовым аспектам религиозной свободы, юридический факультет, Трнавский университет, Словацкая Республика, 91843, Трнава, Горнопоточна, 23; moravcikova@gmail.com

Moravč́ková Michaela - Th.D., director of Institute for Legal Aspects of Religious Freedom, Faculty of Law, Trnava University, 23, Hornopotočná, 91843, Trnava, Slovak Republic; moravcikova@gmail.com

1 This work was supported by Slovak Research and Development Agency under the contract No. APVV-0024-12.

(c) Санкт-Петербургский государственный университет, 2017 
зом, по-прежнему актуальны вопрос о пределах коллективного выражения свободы религии и вопрос о финансировании церквей и религиозных обществ из государственного бюджета. Библиогр. 7 назв.

Ключевые слова: государственно-церковные отношения, религия, признание церквей и религиозных обществ, финансовая поддержка церквей.

\section{Constitutional principles of state neutrality towards religion}

The Constitution of the Slovak Republic, in its preamble acknowledges the spiritual heritage of Cyril and Methodius and the historical legacy of the Great Moravian Empire. In Chapter One of the Constitution of the Slovak Republic in Article 1 the basic principle is to be found: "The Slovak Republic is a sovereign, democratic state governed by the rule of law. It is not bound by any ideology or religion". Article 24 of the Constitution guarantees freedom of thought, conscience, religion and faith. This right includes the right to change religion or faith. Everybody has the right to refrain from a religious affiliation. Every person has the right to express freely his or her own religious conviction or faith, either alone or in association with others, privately or publicly, by worship, religious services and ceremonies, or participate in religious instruction [1, p.216].

The Article 24 is part of the Chapter Two of the Constitution of the Slovak Republic, and it regulates the fundamental rights and freedoms. It contains general provisions, fundamental human rights and freedoms, political rights, rights of national minorities and ethnical groups, economic, social and cultural rights, right to environmental protection and cultural heritage, right to judicial and other protection. The fundamental rights and freedoms create the most extensive part of the Constitution of the Slovak Republic, which follows from the necessity to enshrine the regulation of these rights in the Constitution directly and is one of the most characteristic features of constitutions of democratic countries [2, p.219].

\section{Recognition of Religious Subjects}

The Act 308 (1991)on the freedom of belief and the position of churches and religious societies considers as church or religious society a voluntary association of persons of the same belief, in an organization with own structure, bodies, internal regulations and services. Churches and religious societies are legal entities, and can associate freely. They may create communities, religious orders, associations and similar institutions. Churches and religious societies are special types of legal entity taking advantage of a special status and also other rights awarded to legal entities in general. It is a case particularly of inviolability of privacy, of protection of property, name and inheritance, of inviolability of letters, freedom of movement and residence, freedom of expression and right to information, right to petition, right to assemble and associate, the right to judicial and legal protection etc. The State recognizes only churches and religious societies that are registered. According to the Act 308 the registration body is the Ministry of Culture of the Slovak Republic. The preparatory body of a church or religious society may apply for registration if it can prove that at least 20000 adult persons - citizens of the SR who are domiciled within the territory of the Slovak Republic and claim membership of the church 
or religious society ${ }^{2}$. The application for registration must also contain basic documents of the church or religious society to be founded, as well as affirmations of at least 20000 adult members, who are domiciled within the territory of the SR and are citizens of the Slovak Republic, that they claim allegiance to the church or religious society, support the proposal for its registration, are its members, know its basic articles of faith and its doctrine and are conscious of rights and freedoms following from the church or religious community membership ${ }^{3}$. In the period between coming into force of the Act 308 on the freedom of belief and the position of churches and religious societies, and coming into force of the Act 201 (2007), i.e. until 1 May 2007, only those religious societies were registered that reached the stipulated membership minimum of 20000 . It was expressed by signatures on a petition attached to the basic documents of the church to be founded, which could be signed - according to the then valid legislation, when the details of the registration of churches and religious societies were regulated by the Act 192(1992) on the registration of churches and religious societies - not only by members of the church to be grounded, but also by supporters of its registration ${ }^{4}$. In this way, registration was achieved by the Religious Society of Jehovah's Witnesses (registered in 1993), the Church of Jesus Christ of the Latter-day Saints (registered in 2006), the Baháí Community in the Slovak Republic (registered in 2007). Besides, in 2001 the New Apostolic Church was registered additionally, after it had submitted relevant documents about the State consent to the performance of its activities on the territory of the Slovak Republic before coming into force of the Act 308 (1991) [3, p. 501-502].

Apart from mentioned registered churches and religious societies, other, new and untraditional religious societies are active in Slovakia too. This title ("untraditional religions") is adequate only from the perspective of Slovak reality, because those religions embrace communities derived from ancient religious traditions such as Buddhism, Hinduism and Islam. In general we can name them unregistered religious societies since they have not gained legal personality on the basis of Act No. 308 (1991) on freedom of religious faith and the position of churches and religious societies. Many of them have the status of civil associations, they use other ways of acquiring legal personality (e.g. foundation, non-investment fund, business companies) or do not have legal personality at all. Mormons, Baháí Community, Witnesses Jehovah and New Apostolic Church were recently registered. Unregistered churches wish to be involved in the dialogue with public authorities. They mainly seek to find the possibility to register themselves according to Act No. 308 (1991) on freedom of religious faith and the position of churches and religious societies. They also participate in religious, social and cultural events. Since conditions for the registration are rather strict, discussion about the possibility to change the system of registration is being opened quite often. Perhaps extensive criticism or pressure from abroad led the General Prosecutor to file a motion with the Constitutional Court of the Slovak Republic in which he challenged constitutionality of Act

2 Art. 11 oftheAct 201 (2007).

3 Art. 11d oftheAct 201 (2007).

${ }^{4}$ Cf. Reply of the Ministry of Culture of the SR to the request for information on the basis of the Information Act 211(2000) (MK-65/2001-IZ from June 7, 2001), according to which "laws regulating the registration of churches and religious societies do not stipulate the motivation of persons when signing the signature sheet declaring their affiliation to a church or religious society, therefore it need not mean their membership according to the internal statutes of the given church or religious society". 
No.308 (1991) on freedom of religious faith and the position of churches and religious societies. As indicated in the motion, General Prosecutor considers the condition of especially 20000 declarations of honour (condition for the registration of a church) as unconstitutional and discriminatory. On 3 February 2010 the Constitutional Court rejected the motion of General Prosecutor and decided that the condition of holding the declaration of honour of 20000 citizens of Slovakia with domicile in the territory of the Slovak Republic is not unconstitutional. The court arrived to the conclusion that the registration of a church is not a necessary condition for the possibility to freely express one's belief. Despite the decision of the Constitutional Court, it is expected that small, unregistered churches will be making effort to get legal personality as churches do have. There are several initiatives to introduce a 2-instance registration, as it is e.g. in Czech Republic. On local level, it is expected that cooperation between public authorities and churches and religious societies will intensify [4, p. 621].

In November 2016, members of NationalCouncil (Slovak Parliament) adopted the amendment to the Act 308 (1991) on freedom of religious faith and the position of churches and religious societies. According to this amendment, the preparatory body of a church or religious society may apply for registration if it can prove that at least 50000 adult persons - citizens of the SR who are domiciled within the territory of the Slovak Republic and claim membership of the church or religious society. In December 2016 President of the Slovak republic, making use of the right given to him by law and returned the amendment to the Parliament for repeated consideration. He refused to sign the amendment because considered it as a disproportionate restriction of the right to religious freedom. In the near future we can expect that Parliament will confirm its initial decision. Although MPs in a written explanatory statement reported to economic reasons, later parliamentary debate pointed to security concerns.

\section{Economical support of Churches}

In Slovakia after fall of communism in 1989 new legislation enabled churches and religious communities to have full internal self-government, but it did not eliminate their direct financial dependence on the state. Act 218 (1949) on financial provision for churches and religious communities, as much amended, eliminated a discriminatory approach and state control over the churches, but still maintains a paternalistic approach to the churches in the field of finance. By means of the Act the communist state imposed a unified form of direct state subsidy on churches and religious communities. The subsidy should have superseded the whole spectrum of individually differentiated traditional sources of income. In the period between 25 February 1948 and 1November 1949 when the Act 218 (1949) came into force, a crucial part of the churches' productive property was nationalised without redress, particularly by means of a unilateral implementation of the Acts on land and agrarian reforms. Restitution of church property is one of the processes enabling churches to start working towards economic independence. On the basis of Federal Act 298 (1990) on the regulation of some property relations of monastic orders and congregations and the Olomouc archbishopric as spelt out in Act no 338 (1991) some property of monastic orders and congregations was returned. In the territory of the Slovak Republic, ninety-five monasteries were involved. Act 282 (1993) on the mitigation of some of the legal injustices to property caused to churches and religious communities 
enabled some ownership rights to be restored. This related to movable and immovable things of which churches and religious communities were dispossessed on the basis of decisions of state bodies, civil law and administrative Acts issued in the period between 8 May $1945-2$ November 1938 in the case of Jewish communities - and 1 January 1990. The Act stipulated that proceedings relating to the surrender of immovable things be exempt from administrative and court fees, and compensation for costs connected with the geographical location of surrendered real estate must be provided by the State. Act no. 97 (2002) amending Act 282 (1993) added to the property to be restored lands that are the part of the forest land in national parks.

At present, on the basis of Act 218 (1949) and its amendment by Act 522 (1992), the State must provide churches and religious communities with funds for payment of their clergy stipends (including contributions to social and health care funds and the employment fund), if churches and religious communities so request. Churches and religious communities that were provided with personal benefits for their clergy up to 31 December 1989 are not obliged to do this. The classification and levels of clergy stipends are regulated by SR Government decree. The State contributes to the operation of the headquarters of registered churches and religious communities. The Ministry of Culture of the Slovak Republic is the administrator of the financial support assigned in the national budget by the National Council for churches and religious communities. Through the church department it remits assigned funds to each church headquarters on a monthly basis. All proceeds of church collections, income for church activities, and regular contributions of registered churches' and religious communities' members are tax exempt. The value of gifts provided for humanitarian, charitable and religious purposes of the churches and religious communities registered by the State may be deducted from the taxable income of natural persons and legal entities to the amount stipulated by the Act. Lands forming one functional unit with a building or part of a building which is used for the performance of religious ceremonies, and with the whole or part of a building which serves as offices for persons commissioned for church administration, are exempt from land tax. Lands where cemeteries are founded are also exempt from land tax. Buildings and those parts of them used exclusively for the performance of religious ceremonies or as the offices of church administrators are exempt from the tax on buildings. Legacies and gifts earmarked for the development of registered churches and religious communities are exempt from inheritance tax. Under conditions stipulated by Ordinance no. 17 (1994) religious objects and gifts for churches and religious communities are exempt from import duty. On the basis of Section 48 of Act 366 (1999) on tax on earnings, as amended by later regulations, each taxpayer is entitled to remit, through the tax administrator, a sum of money equivalent to $2 \%$ of his or her income tax to one of the specified legal entities among which are agencies of churches and religious communities. In addition to this, churches and religious communities as well as entities with legal personality derived from them, may apply for various grants and subsidies. Churches may apply for grants towards the preservation and recovery of cultural landmarks that are in their ownership as well as for social, charitable, educational and cultural projects [5, p. 68].

Despite the restitution of church property in the early period after the fall of communism, the State is not able to return all nationalized property to the churches. Part of this property is serving to the public or military purposes. It's one of reasons 
of preferring the preservation of the old system of financing from the state budget. Since 2000 it was established and worked several expert commissions seeking for new model of financing of churches in the Slovak Republic. This task has been underlined by the signing ofthe Basic Treaty between the Slovak Republic and the Holy See in 2000 [6, p. 465]. This important source of law has settled, inter alia, that the parties would conclude four other so called partial treaties. One of them will be Treaty on the financial support of the Catholic Church, as anticipated by articles 7 and 20 of the Basic Treaty between the SR and the Holy See 326 (2001). Also Agreement between the Slovak Republic and the Registered Churches and Religious Societies in the Slovak Republic 250 (2002) anticipated partial Treaty on the financial support of (non-catholic, registered) churches. The state is thus determined either approve three new documents on the financing of churches and religious communities: new Act or amendment to the Act and two partial treaties.

\section{Conclusion}

State - Churchrelations in the Slovak Republiccan be evaluated as a relation of partnership and cooperation. Naturally, the current State-Church Law system shows signs of previous periods of oppression of religious life and economic entire dependence from the State. This applies to state-recognized, registered churches and religious communities - those that fulfilled conditions for registration or has been recognized for historical reasons. New religious movements are practically unable to obtain public legal personality because they are naturally small in number of their members. Current development heads to more strict condition for obtaining of status of officially recognized Church in Slovakia. Both, economic and security reason are actually mentioned.

Although the Slovak Republic is a secular state and is not bound by any ideology or religion, so called historic churches influence and is felt. Although communism fell down twenty eight years ago, the strong arm of the state in Church policies of the state is felt too. It seems that radical change is not possible at the moment. It seems that even the churches and religious communities does not want radical change and entire new model of their financial life such as Church tax or tax assignation [7, p. 212]. Decades of communism during which churches and religious communities were dependent upon the state represents a significant rift in the natural historical development of church life in the public sphere.

\section{References}

1. Moravčíková M. Law, religion and belief in Slovakia, the Czech Republic and Poland. Cumper P., Lewis T. (eds.) Religion, Rights and Secular Society. Cheltenham, Edward Elgar Publishing, 2012, pp. 215232.

2. Moravčíková M. Law and Religion in Slovakia, the Czech Republic and Poland. Cumper P., Lewis T. (eds.) Religion, Rights and Secular Society. Cheltenham, Edward Elgar Publishing, 2012, pp. 215-232.

3. Moravčíková M. State and Church in the Slovak Republic. Robbers G. (ed.) State and Church in the European Union. Baden-Baden, Nomos, 2005, pp. 491-518.

4. Moravčíková M. Religion, Law, and Secular Principles in the Slovak Republic. Martínez-Torrón J., Durham Jr., Cole W. (eds.) Religion and the Secular State: National Reports / La religion et l'État laïque: Rapports nationaux. The International Center for Law and Religion Studies, Provo, Brigham Young University Publ., 2010, pp.615-628. 
5. Moravčíková M., Cipár M. Cisárovo Cisárovi. Ekonomické zabezpečenie cirkví a náboženských spoločností [Caesar's to Caesar. The economic funding of churches and religious societies]. Bratislava, Ústav pre vztahy štátu a cirkví, 2001. 280 p. (In Slovak)

6. Němec D. Concordat Agreements betwen the Holy See and the Post-Communist States. Leuven, Peeters, 2012. $544 \mathrm{p}$.

7. Šabo M. Model financovania katolíckej cirkvi v SR [Model of financing of Catholic Church in SR]. Bratislava, Ústav pre vztahy štátu a cirkví, 2001. 238 p. (In Slovak)

For citation: Moravč́ková M. The question of secular state, recognition of religious subjects and their economical support. Vestnik SPbSU. Philosophy and Conflict studies, 2017, vol.33, issue 3, pp. 374-380. DOI: 10.21638/11701/spbu17.2017.313.

Received 12.11.2016

Accepted 16.03.2017 